\title{
Nutrient cycling in the water column of a subtropical seagrass meadow
}

\author{
Susan Ziegler*, Ronald Benner** \\ Marine Science Institute, University of Texas at Austín, 750 Channelview Drive, Port Aransas, Texas 78373, USA
}

\begin{abstract}
The cycling of nutrients was studied over a 16 mo period to determine how processes occurring between the water column and benthos influenced nutrient dynamics in a Thalassia testudinum dominated seagrass meadow. Nutrient concentrations were low and ranged from below detection to $0.59 \mu \mathrm{M}$ ammonium $\left(\mathrm{NH}_{4}{ }^{+}\right), 0.04$ to $0.29 \mu \mathrm{M}$ nitrate plus nitrite $\left(\mathrm{NO}_{3}{ }^{-}+\mathrm{NO}_{2}{ }^{-}\right)$, and below detection to $0.22 \mu \mathrm{N}$ soluble reactive phosphate (SRP). Water column and benthic fluxes of $\mathrm{NO}_{3}{ }^{-}+\mathrm{NO}_{2}{ }^{-}$ and SRP were usually below detection. The benthic fluxes of $\mathrm{NH}_{4}{ }^{+}$ranged from an uptake of $-228 \mu \mathrm{mol}$ $\mathrm{N} \mathrm{m}^{-2} \mathrm{~d}^{-1}$ to a release of $363 \mu \mathrm{mol} \mathrm{N} \mathrm{m} \mathrm{N}^{-2} \mathrm{~d}^{-1}$. Positive fluxes (i.e. directed out of the sediment) occurred primarily in light incubations and from seagrass-dominated sediments. Water column fluxes of $\mathrm{NH}_{4}^{+}$ ranged from a net uptake of $-145 \mu \mathrm{mol} \mathrm{N} \mathrm{m}{ }^{2} \mathrm{~d}^{-1}$ to a net regeneration of $643 \mu \mathrm{mol} \mathrm{N} \mathrm{m}{ }^{-2} \mathrm{~d}^{-1}$. The net regeneration of $\mathrm{NH}_{4}{ }^{+}$in the water column usually exceeded the release of $\mathrm{NH}_{4}{ }^{+}$from the benthos. There was a significant correlation between the regeneration of $\mathrm{NH}_{4}{ }^{+}$in the water column and the light-mediated release of dissolved organic matter (DOM) from the benthos, indicating that benthicderived DOM supported the regeneration of $\mathrm{NH}_{4}{ }^{+}$in the water column. Bacterioplankton growth efficiencies were significantly and positively correlated to the regeneration of $\mathrm{NH}_{4}{ }^{+}$in the water column, possibly resulting from changes in the composition of DOM released from the benthos. The C: $N$ ratios of the organic matter remineralized in the water column were variable and ranged from 14 to 81 , with lowest values occurring in late summer and highest values in spring. The results of this study indicated that temporal variations in the source and composition of DOM significantly influenced the cycling of nutrients in the water column of this seagrass meadow.
\end{abstract}

KEY WORDS: Nutrient cycling $\cdot$ Seagrasses $\cdot$ Benthic fluxes $\cdot$ Ammonium $\cdot$ Dissolved organic matter

\section{INTRODUCTION}

Seagrass-dominated estuaries are among some of the most productive ecosystems on earth, supporting and serving as nurseries for commercially important species and feeding grounds for waterfowl (Hillman et al. 1989). Worldwide degradation of seagrass meadows is well documented (Dennison et al. 1993), with losses attributed to increased human activities in coastal areas. For example, the coincidence of areas of greatest reduction in aquatic grasses with areas of greatest

\footnotetext{
Present addresses:

- Carnegie Institution of Washington, Geophysical Laboratory, 5251. Broad Branch Rd. NW, Washington, DC 200151305, USA.E-mail: ziegler@gl.ciw.edu

- Department of Biological Sciences, University of South Carolina, Columbia, South Carolina 29208, USA
}

nutrient enrichment has been reported throughout the Chesapeake Bay (Orth \& Moore 1983). Nutrient enrichment has been found to increase epiphytic growth on seagrasses and possibly trigger algal blooms, both causing dramatic reductions in seagrass populations (Kemp et al. 1983, Borum 1985, Flores-Verdugo et al. 1988, Dunton 1990). Increases in dissolved inorganic nitrogen (DIN), possibly due to increases in agricultural practices as well as a massive fish kill, may have been responsible for the onset of a brown tide in northern Laguna Madre, Texas, in June 1990 (Whitledge 1993). This brown tide has been implicated in about a $20 \%$ reduction of the seagrass Halodule wrightii between. 1992 and 1995, and has dramatically increased the phytoplankton to seagrass production ratio in northern Laguna Madre (Stockwell et al. 1993, Onuf 1996).

To help determine the influence of environmental changes, such as increases in nutrient loading, on sea- 
grass ecosystems there is a need to understand the biogeochemical cycling of nutrients within these systems. Nutrient dynamics in seagrass meadows and other shallow environments is typically dominated by benthic processes. Because concentrations of nutrients are low in the water column, seagrasses most likely obtain their nutrients from the sediments where concentrations are considerably higher (Iizumi et al. 1982, Short \& McRoy 1984, Blackburn et al 1994). Rapid recycling of nitrogen $(\mathrm{N}$ ) in the sediments has been documented in seagrass systems and appears to occur more rapidly in sediments dominated by seagrasses versus those that are unvegetated (Boon et al. 1986). Iizumi et al. (1982) and Short (1983) estimated that about 28 and $60 \%$, respectively, of the ammonium $\left(\mathrm{NH}_{4}{ }^{+}\right)$regenerated in the sediment of seagrass beds was released to the overlying waters. Remineralization of nutrients and nitrogen fixation in the benthos appear to be fueled by seagrass photosynthate released through the roots (Jørgensen et al. 1981, Moriarty et al. 1986, Blackburn et al. 1994, Stapel \& Hemminga 1997). The release and remineralization of seagrass photosynthate in the benthos represents a possible source of inorganic $\mathrm{N}$ and $\mathrm{P}$ in the overlying water column in these ecosystems.

A significant fraction of the carbon fixed by seagrasses is released as dissolved organic matter (DOM) into the water column through leaching and exudation and is subsequently utilized by heterotrophic bacterioplankton (Moriarty \& Pollard 1982, Moriarty et al. 1986. Chin-Leo \& Benner 1991, Ziegler \& Benner 1999). For example, water column respiration accounts for about $60 \%$ of benthic net primary production in a Thalassia testudinum meadow of Laguna Madre (Ziegler \& Benner 1999). The activity of benthic algae and macrophytes has been found to stimulate bacterioplankton production and nutrient cycling in shallow estuaries where dissolved organic nitrogen appears to be the major form of $\mathrm{N}$ released from the benthos (Moriarty et al. 1986, Middelboe et al. 1998).

The influence of the benthic release of DOM on bacterioplankton activity has been observed, however, very little is known about its influence on nutrient cycling in seagrass ecosystems. How does the coupling of processes between the water column and the benthos influence the cycling of nutrients in these ecosystems? Does the remineralization of DOM serve as a major source of inorganic nitrogen or phosphorus? If so, is this source influenced by seasonal variations in the source of DOM such as seagrass exudation and leaching? The purpose of this study was to address these questions by determining the abundance and cycling of nutrients in the water column of lower Laguna Madre. Water column concentrations were investigated, as well as benthic and water column fluxes of $\mathrm{NH}_{4}{ }^{+}$, nitrate plus nitrite $\left(\mathrm{NO}_{3}{ }^{-}+\mathrm{NO}_{2}{ }^{-}\right)$, and soluble reactive phosphate (SRP) from June 1996 to June 1997. These nutrient parameters were examined in relation to measurements of phytoplankton and bacterioplankton production, benthic production, respiration, and dissolved organic carbon fluxes.

\section{MATERIALS AND METHODS}

Site description. Laguna Madre is the southernmost estuary located on the Texas coast, and it is separated from the Gulf of Mexico by Padre Island. Our study was conducted in a Thalassia testudinum dominated seagrass meadow in the southern portion of Laguna Madre. Beds of Syringodium filiforme and Halodule wrightii as well as drift algal species such as Digenia simplex and Laurencia poitei also occur in southern Laguna Madre (Humm \& Hildebrand 1962, Onuf 1996). The study site was located east of the Gulf Intracoastal Waterway at about $26^{\circ} 10^{\prime} \mathrm{N} 97^{\circ} 12^{\prime} \mathrm{W}$. (For map see Herzka \& Dunton 1996.) A total of ten 5 day trips were made to southern Laguna Madre approximately every 6 to $8 \mathrm{wk}$ from February 1996 to June 1997. Data from 2 of these 10 trips are not presented here due to brown tide blooms which interfered with the collection of nutrient data

Water column parameters. Water temperature and depth were recorded using a data logging system (YSI6000, YSI Inc.) secured at mid-depth ( $-0.5 \mathrm{~m})$ for the duration of each trip. Average $\mathrm{NH}_{4}{ }^{+}, \mathrm{NO}_{3}{ }^{-}+\mathrm{NO}_{2}{ }^{-}$, and SRP concentrations were determined from 12 to 24 samples collected over a 24 h period using an autosampler (see Ziegler \& Benner 1998) Samples were collected in $45 \mathrm{ml}$ glass bulbs (acid washed) at 60,70 or $120 \mathrm{~min}$ intervals from about $0.6 \mathrm{~m}$ depth. Sample bulbs were kept in the dark and collected from the sampler every $12 \mathrm{~h}$ around sunrise and sunset. The $45 \mathrm{ml}$ samples were transferred from the bulbs into $125 \mathrm{ml}$ high-density polyethylene bottles (acid washed) and immediately placed on ice. Samples were frozen within $4 \mathrm{~h}$ of collection. All nutrient samples were analyzed within $4 \mathrm{wk}$ of collection.

Seagrass carbon and nitrogen. Whole live plants were collected using a $15 \mathrm{~cm}$ diameter corer at the study site in July, September, and November. The cores were sieved with water to remove live plants from the sediment. The plants were rinsed with seawater and then kept on ice until they were brought back to the lab. The tissues were rinsed with distilled water and separated into above-(blades) and below-ground (roots and rhizomes) tissues. Once separated, the tissues were placed in a drying oven at $45^{\circ} \mathrm{C}$ for $48 \mathrm{~h}$. The dried tissues were milled, and carbon and nitrogen content were determined on a Carlo Erba EA 1108 elemental analyzer. 
Water column production, respiration, and nutrient fluxes. Water was collected around dawn and incubated in light and dark bottles (300 ml biological oxygen demand bottles or $90 \mathrm{ml}$ quartz bottles) for about $12 \mathrm{~h}$ during the day to estimate primary production, respiration, and net fluxes of nutrients in the water column. Another water sample was collected around sunset and incubated overnight in dark bottles to estimate respiration and nutrient fluxes at night. Dark bottles were wrapped in aluminum foil, and all bottles were incubated in situ on racks set at mid-depth $(-0.5 \mathrm{~m})$ in the water column. To estimate primary production and respiration, changes in dissolved oxygen were determined in light and dark incubations using Winkler titrations with an automated titrator and potentiometric endpoint detection (Biddanda et al. 1994). Rates of net $\mathrm{O}_{2}$ production or consumption were determined from the slope of the least-square linear regression $(n \geq 6)$ of the dissolved oxygen data versus time. Consumption of dissolved oxygen in dark incubations during the daytime were added to the value for light incubations to obtain estimates of gross primary production. Water column gross primary production and respiration rates based on $\mathrm{O}_{2}$ were converted to units of carbon using photosynthesis and respiration quotients of 1.2 and 1.0 , respectively (Oviatt et al. 1986).

Rates of net nutrient production or consumption were determined from the slope of the least-square linear regression analysis of nutrient concentration versus time $(n \geq 6$ ). Initial and final samples were dispensed into clean $125 \mathrm{ml}$ polyethylene bottles, immediately placed on ice and frozen within $4 \mathrm{~h}$ of collection. The daily net flux of nutrients occurring in the light was based on the number of daylight hours. The number of hours of light for each day was based on the number of hours of saturating PAR light for seagrasses $\left(-300 \mu \mathrm{E} \mathrm{m}^{-2} \mathrm{~s}^{-1}\right.$; Herzka \& Dunton 1996) determined from underwater continuous PAR light data collected close to the study site (K. Dunton, J. Kaldy \& J. Kowalski unpubl. data). The daily net dark flux was calculated from the number of hours below saturating light levels. Daily net regeneration of $\mathrm{NH}_{4}{ }^{+}$in the water column (dark incubations) was calculated from the sum of the water column fluxes estimated for daytime and nighttime. Positive fluxes indicated net regeneration and negative fluxes indicated the net uptake of the nutrient

Bacterioplankton production. Bacterioplankton production was estimated from protein synthesis using ${ }^{3} \mathrm{H}$-leucine (Kirchman et al. 1985). Triplicate $20 \mathrm{ml}$ samples were incubated in the dark with ${ }^{3} \mathrm{H}$-leucine (20 nM final concentration, specific activity of $50 \mathrm{Ci}$ $\mathrm{mmol}^{-1}$, New England Nuclear) for $1 \mathrm{~h}$ in a circulating bath of Laguna Madre water. One formaldehyde $14 \%$ final concentration) killed control was run with each triplicate live sample set to determine abiotic sorption of the labeled leucine. Incubations were terminated by filtration through a $0.2 \mu \mathrm{m}$ pore-sized MF Nucleopore membrane filter. Filters were immediately extracted with ice cold $5 \%$ trichloroacetic acid for $5 \mathrm{~min}$, followed by a $5 \mathrm{ml}$ rinse with ice-cold trichloroacetic acid stored in scintillation vials and refrigerated until measurement of radioactivity within $7 \mathrm{~d}$ of collection. Prior to scintillation counting samples were extracted at $50^{\circ} \mathrm{C}$ for $1 \mathrm{~h}$ using the tissue solubilizer Solvable (Dupont, New England Nuclear Inc.) as described by Amon \& Benner (1998). Rates of bacterial carbon production were estimated from leucine incorporation rates using conversion factors of $4.3 \times 10^{16} \mathrm{cells}^{\mathrm{mol}}{ }^{-1}$, derived from experiments using Laguna Madre water (Chin-Leo \& Benner 1991), and $20 \mathrm{fg} \mathrm{C} \mathrm{Cell}^{-1}$ (Lee \& Fuhrman 1987).

Bacterial growth efficiencies were calculated as the ratio of bacterial production to bacterial production plus water column respiration, except in March 1997. During March 1997 primary production was relatively high due to the presence of a brown tide. Respiration due to bacterioplankton, at this time, was assumed to be $70 \%$ of the total plankton respiration. This assumption was based on previous measurements of bacterial respiration ranging from 40 to $100 \%$ of plankton respiration for different marine environments (Williams 1981, Chin-Leo \& Benner 1992, Biddanda et al. 1994).

Benthic nutrient fluxes. Net fluxes of $\mathrm{NH}_{4}{ }^{+}, \mathrm{NO}_{3}{ }^{-}+$ $\mathrm{NO}_{2}{ }^{-}$and SRP into and out of the benthos were determined by measuring changes in nutrient concentrations in light and dark chambers. Chambers were constructed from 20 I Nalgene polycarbonate carboys by removing the bottoms and adding a sampling port at the shoulder. Caps of the chambers were fitted with a current-driven stirring mechanism to mimic in situ water movement (see Ziegler \& Benner 1998). Covers for the chambers were constructed of dark-gray plastic and used for the dark incubations. Four chambers were placed carefully about $8 \mathrm{~cm}$ into the sediment at 3 seagrass-dominated sites (primarily Thalassia testudinum) and 1 unvegetated area (void of all macrophytes) adjacent to the other chambers. An average of the 4 chambers was used to estimate net benthic nutrient fluxes in lower Laguna Madre. The distribution of chambers was based on estimates of the aerial coverage of seagrass-dominated (75\%) and unvegetated (25\%) sediments in lower Laguna Madre (Quammen \& Onuf 1993). Positive flux values indicated a net flux from the sediments to the water column, and negative fluxes indicated a net flux from the water column into the sediments.

Benthic chambers were carefully deployed without caps the day prior to the benthic measurements. At 
dawn, water in the chambers was exchanged with overlying water using a hand-held pump. Dark incubations were conducted early in the morning and late in the afternoon to avoid dramatic shifts in light levels. Incubations lasted for 1.5 to $4 \mathrm{~h}$ depending upon level of activity (i.e. incubations were the longest in winter and shortest in summer). Samples were collected for nutrient analysis through the sampling port using a $60 \mathrm{ml}$ syringe, dispensed into $125 \mathrm{ml}$ high-density polyethylene bottles and treated as described for the diel water column samples. After completion of all benthic incubations, volumes for all 4 chambers were determined by injecting each with $15 \mathrm{ml}$ of $30 \mathrm{mM} \mathrm{NaNO}_{3}$. Each chamber was stirred for 2 min before a sample was collected and later frozen. The concentration of $\mathrm{NO}_{3}{ }^{-}$in these samples was used to estimate the volume of each chamber during every trip. Nutrient fluxes measured in the water column were used to correct the benthic nutrient fluxes for changes in nutrient concentrations due to processes occurring in the water contained in each chamber. The daily net benthic flux of nutrients occurring in the light was based on the number of hours of saturating PAR light levels for seagrasses, and the daily net fluxes occurring at night were calculated from the number of hours below saturating light levels.

Nutrient analyses. All samples collected for nutrient analyses were unfiltered to avoid additional steps that could have caused contamination in these samples with low concentrations of nutrients. In March, however, all samples were passed through a GF/F filter immediately after collection because of the unusually high phytoplankton production caused by a brown tide bloom that occurred in the previous months. There was no difference between $0.2 \mu \mathrm{m}$ (polycarbonate) filtered water and whole water collected in April, June, July, September and November with respect to $\mathrm{NH}_{4}{ }^{+}, \mathrm{NO}_{3}{ }^{-}$ $+\mathrm{NO}_{2}{ }^{-}$concentrations (Table 1). There was a difference in SRP concentration between the $0.2 \mu \mathrm{m}$ filtered water and whole water collected in April; however, SRP was usually below detection in both the filtered and unfiltered water (Table 1).
Concentrations of $\mathrm{NH}_{4}{ }^{+}$were determined using the phenol-hypochlorite method (Solorzano 1969). The detection limit was $0.30 \mu \mathrm{M}$ at a confidence level $\geq 89 \%$. The precision of the $\mathrm{NH}_{4}{ }^{+}$analysis at $0.3 \mu \mathrm{M}$ was $15 \%$ (expressed as coefficient of variance). Concentrations of $\mathrm{NO}_{3}{ }^{-}+\mathrm{NO}_{2}^{-}$were determined for $10 \mathrm{ml}$ samples using the standard cadmium reduction method modified for small samples (Gardner et al. 1976). Imidazole buffer was used in place of the $\mathrm{NH}_{4} \mathrm{Cl}$ in both the additions to the sample $(0.05 \mathrm{M}, \mathrm{pH}=7.5)$ and through the column itself $(0.1 \mathrm{M}, \mathrm{pH}=7.5)$ in order to avoid $\mathrm{NO}_{3}{ }^{-}$ contamination often found in reagent grade $\mathrm{NH}_{4} \mathrm{Cl}$. Standards of $\mathrm{KNO}_{3}$ and $\mathrm{NaNO}_{3}$ were analyzed before and after every set of samples. The detection limit for $\mathrm{NO}_{3}{ }^{-}+\mathrm{NO}_{2}^{-}$was $0.02 \mu \mathrm{M}$, and precision was 40 and $4 \%$ at 0.02 and $1.00 \mu \mathrm{M}$, respectively. Samples collected in June 1997 were analyzed for $\mathrm{NO}_{3}{ }^{-}+\mathrm{NO}_{2}{ }^{-}$ using an Antek Model 745 Nitrate/Nitrite Reduction Assembly and Antek Model 7020 nitric oxide chemiluminescence detector. The precision for $1 \mathrm{nM} \mathrm{NO}_{3}^{-}+$ $\mathrm{NO}_{2}^{-}$was $<6 \%$ using chemiluminescence detection. SRP was determined using the standard colormetric method (Strickland \& Parsons 1972). The detection. limit was $70 \mathrm{nM}$ and the precision was $1 \%$ at $70 \mathrm{nM}$.

\section{RESULTS}

\section{Water column nutrient concentrations}

Nutrient concentrations in the water column of southern Laguna Madre were low throughout the year as compared with most estuarine systems, and relative to most seagrass systems (Fig. 1) Considerably higher nutrient concentrations have been reported in other tropical and temperate seagrass meadows (Pederson \& Borum 1993, Johnson \& Johnstone 1995, Stapel et al. 1997). $\mathrm{NH}_{4}{ }^{+}$concentrations in lower Laguna Madre ranged from <0.30 to $0.59 \mu \mathrm{M}$ and were highest in the late summer (Table 2, Fig. 1). $\mathrm{NO}_{3}^{-}+\mathrm{NO}_{2}^{-}$concentrations ranged from 0.04 to $0.18 \mu \mathrm{M}$, with the lowest concentrations in the sum-

Table 1. Average nutrient concentrations $(\mu \mathrm{M})$ of whole and filtered $(0.2 \mu \mathrm{m})$ water samples. Each value is reported as the mean $(\mathrm{n} \leq 3) \pm 1$ SD. SRP: soluble reactive phosphorus

\begin{tabular}{|c|c|c|c|c|c|c|}
\hline \multirow[t]{2}{*}{ Month } & \multicolumn{2}{|c|}{$\mathrm{NH}_{4}{ }^{+}$} & \multicolumn{2}{|c|}{$\mathrm{NO}_{3}^{-}+\mathrm{NO}_{2}^{-}$} & \multicolumn{2}{|c|}{ SRP } \\
\hline & Whole water & $0.2 \mu \mathrm{m}$ & Whole water & $0.2 \mu \mathrm{m}$ & Whole water & $0.2 \mu \mathrm{m}$ \\
\hline April & $0.22 \pm 0.08$ & $0.23 \pm 0.05$ & $0.07 \pm 0.01$ & $0.04 \pm 0.02$ & $0.10 \pm 0.02$ & $<0.07$ \\
\hline June & $0.21 \pm 0.03$ & $0.26 \pm 0.03$ & $0.12 \pm 0.03$ & $0.14 \pm 0.02$ & $<0.07$ & $<0.07$ \\
\hline July & $0.45 \pm 0.10$ & $0.43 \pm 0.02$ & $<0.02$ & $<0.02$ & $<0.07$ & $<0.07$ \\
\hline September & $0.28 \pm 0.07$ & $0.29 \pm 0.04$ & $0.02 \pm 0.02$ & $0.05 \pm 0.05$ & $<0.07$ & $<0.07$ \\
\hline November & $0.31 \pm 0.08$ & $0.25 \pm 0.02$ & $0.06 \pm 0.01$ & $0.08 \pm 0.00$ & $<0.07$ & $<0.07$ \\
\hline
\end{tabular}




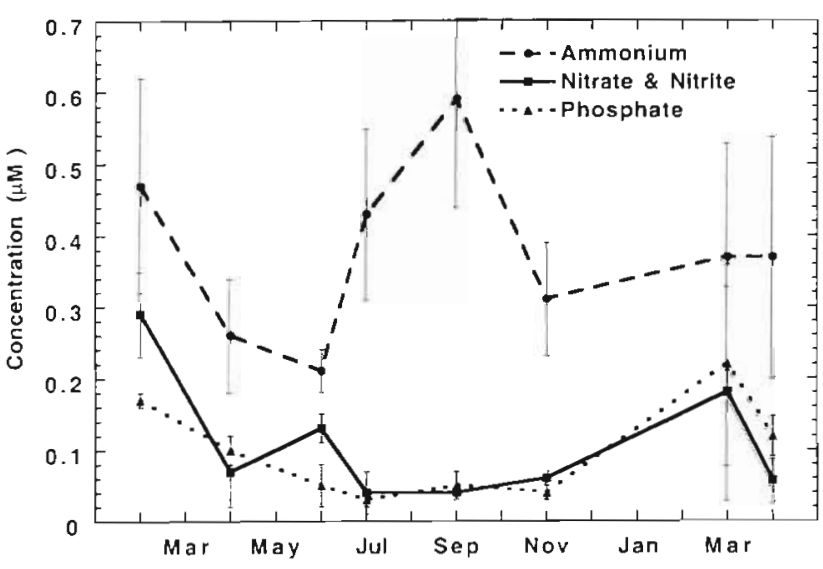

Fig. 1. Mean ammonium, nitrate + nitrite, and soluble reactive phosphate concentrations in the water column at the study site from February 1996 through June 1997. Error bars represent $\pm 1 \mathrm{SD}$

mer and fall. SRP was generally below detection limit and ranged from $<0.07$ to $0.17 \mu \mathrm{M}$. $\mathrm{NO}_{3}{ }^{-}+\mathrm{NO}_{2}{ }^{-}$, and SRP concentrations peaked in March when phytoplankton production was the highest due to a brown tide. The concentration of SRP remained high in June 1997 when phytoplankton production remained higher than normal. There was no apparent diel pattern in water column nutrient concentrations except in March 1997, when $\mathrm{NH}_{4}^{+}$concentrations increased during the day and decreased at night (Fig. 2). Concentrations of SRP in Florida Bay (annual average of $0.03 \mu \mathrm{M}$ ) were similar to those in lower Laguna Madre, whereas DIN concentrations (annual average of $2.7 \mu \mathrm{M}$ ) were generally higher (Fourqurean et al. 1993). The ratios of DIN to SRP in lower Laguna Madre were below the Redfield ratio of 16:1 (Redfield 1958) during the spring and winter (Table 2). From April through November 1996, SRP was not detectable and thus only minimal values for the ratio of DIN to SRP could be calculated.

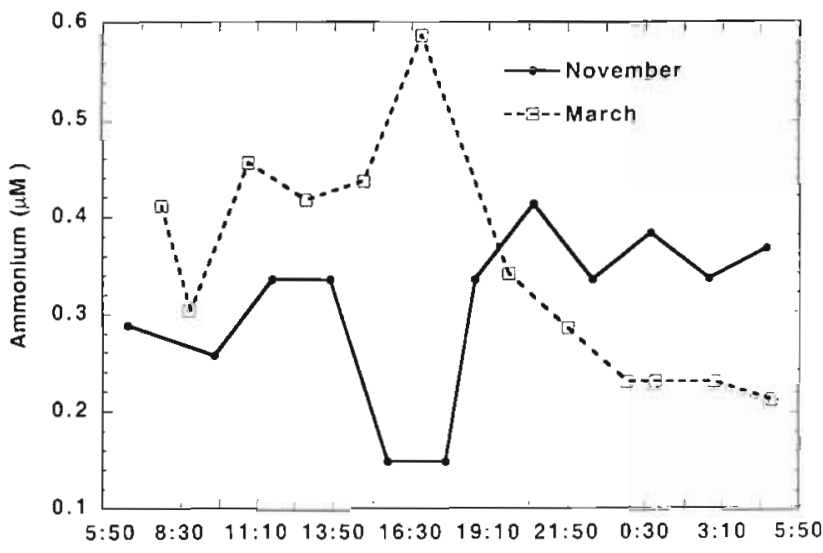

Fig. 2. Diel water column ammonium concentrations collected. at the study site on November 5-6, 1996 and March 8-9, 1997

\section{Seagrass carbon and nitrogen content}

The $\mathrm{C}$ and $\mathrm{N}$ content of above- and below-ground Thalassia testudinum tissues collected in July, September, and November indicated that there were large differences in the $\mathrm{N}$ content of the seagrass tissues between the summer and fall (Table 3 ). The $\mathrm{C}$ and $\mathrm{N}$ content decreased slightly from July to September in both the above-and below-ground tissues. Molar C:N ratios of the above- and below-ground tissues collected in July and September were similar. The C:N ratios were much lower in November due to a higher $\mathrm{N}$ content in both the above- and belowground tissues. The $\mathrm{N}$ content of the seagrasses collected in November were 28 and $111 \%$ higher in the above- and below-ground tissues, respectively, than those collected in September. The higher $N$ content of the tissues in November suggests that $N$ storage in the fall could help support rapid growth in the spring (Pedersen \& Borum 1993).
Table 2. Mean water temperature, ammonium $\left(\mathrm{NH}_{4}{ }^{+}\right)$, nitrate plus nitrite $\left(\mathrm{NO}_{3}{ }^{-}\right.$ $+\mathrm{NO}_{2}{ }^{-}$), and soluble reactive phosphorus (SRP) concentrations, and the ratio of dissolved inorganic nitrogen (DIN) to SRP. All errors are reported as $\pm 1 \mathrm{SD}$

\begin{tabular}{|lccccc|}
\hline Month & $\begin{array}{c}\text { Temperature } \\
\left({ }^{\circ} \mathrm{C}\right)\end{array}$ & $\begin{array}{c}\mathrm{NH}_{4}{ }^{+} \\
(\mu \mathrm{M})\end{array}$ & $\begin{array}{c}\mathrm{NO}_{3}{ }^{-}+\mathrm{NO}_{2}{ }^{-} \\
(\mu \mathrm{M})\end{array}$ & $\begin{array}{c}\text { SRP } \\
(\mu \mathrm{M})\end{array}$ & $\begin{array}{c}\text { DIN:SRP } \\
\text { Ratio }\end{array}$ \\
\hline February & $22.1 \pm 1.6$ & $0.41 \pm 0.09$ & $0.29 \pm 0.04$ & $0.17 \pm 0.01$ & 4.11 \\
April & $22.7 \pm 1.4$ & $<0.30$ & $0.07 \pm 0.05$ & $<0.07$ & $>5.29$ \\
June & $30.2 \pm 0.6$ & $<0.30$ & $0.13 \pm 0.02$ & $<0.07$ & $>4.86$ \\
July & $30.7 \pm 0.1$ & $0.43 \pm 0.12$ & $0.04 \pm 0.03$ & $<0.07$ & $>6.71$ \\
September & $30.5 \pm 0.1$ & $0.59 \pm 0.15$ & $0.04 \pm 0.00$ & $<0.07$ & $>9.00$ \\
November & $23.9 \pm 1.7$ & $0.31 \pm 0.08$ & $0.06 \pm 0.01$ & $<0.07$ & $>5.29$ \\
March & $20.7 \pm 1.5$ & $0.37 \pm 0.16$ & $0.18 \pm 0.15$ & $0.13 \pm 0.07$ & 4.23 \\
June & $27.3 \pm 1.5$ & $0.37 \pm 0.17$ & $0.06 \pm 0.03$ & $0.12 \pm 0.03$ & 3.58 \\
\hline
\end{tabular}

\section{Water column production and respiration}

Water column gross primary production was generally low, ranging from 0.4 to $9.2 \mathrm{mmol} \mathrm{C} \mathrm{m}^{-2} \mathrm{~d}^{-1}$, except during January 1997, when it was as high as $35.5 \mathrm{mmol} \mathrm{C} \mathrm{m}^{-2} \mathrm{~d}^{-1}$ due to a brown tide bloom (Table 4). The water column was almost always net heterotrophic, with respiration ranging from 6.6 to $27.0 \mathrm{mmol} \mathrm{C} \mathrm{m} \mathrm{m}^{-2} \mathrm{~d}^{-1}$ (Table 4). Bacterioplankton production in the water column ranged from 1.8 to $9.1 \mathrm{mmol} \mathrm{C}$ 
Table 3. Carbon (C) and nitrogen (N) content of live seagrass blades and roots and rhizomes. The carbon to nitrogen ratios $(\mathrm{C}: \mathrm{N})$ are reported as the molar ratio. Total plant $\mathrm{C}: \mathrm{N}$ is calculated assuming $85 \%$ of the total plant biomass is in belowground tissues (Kaldy 1997)

\begin{tabular}{|llcccc|}
\hline Month & Tissue type & $\begin{array}{c}\mathrm{C} \\
(\mathrm{wt} \%)\end{array}$ & $\begin{array}{c}\mathrm{N} \\
(\mathrm{wt} \%)\end{array}$ & $\begin{array}{c}\text { C:N Total plant } \\
\mathrm{C}: \mathrm{N}\end{array}$ \\
\hline July & Blades & 34.97 & 2.08 & 19.62 & 39.06 \\
& Roots/rhizome & 36.06 & 0.89 & 47.03 & \\
September & Blades & 32.45 & 1.89 & 20.03 & 42.06 \\
& Roots/rhizome & 33.30 & 0.75 & 51.87 & \\
November & Blades & 33.57 & 2.41 & 16.27 & 22.63 \\
& Roots/rhizome & 32.89 & 1.58 & 24.35 & \\
& & & & & \\
\end{tabular}

$\mathrm{m}^{-2} \mathrm{~d}^{-1}$ and was similar to bacterial production rates measured in the water column over other subtropical seagrass meadows, including upper Laguna Madre (Moriarty \& Pollard 1982, Moriarty et al. 1990, ChinLeo \& Benner 1991). The estimated bacterioplankton growth efficiencies ranged from 21 to $38 \%$ and fell within the range of most aquatic ecosystems studied (del Giorgio et al. 1997).

\section{Water column and benthic nutrient fluxes}

Net regeneration of $\mathrm{NH}_{4}{ }^{+}$in the water column occurred primarily in the dark and ranged from 45 to $643 \mu \mathrm{mol} \mathrm{N} \mathrm{m}^{-2} \mathrm{~d}^{-1}$ or 0.04 to $0.55 \mu \mathrm{mol} \mathrm{N} \mathrm{I}^{-1} \mathrm{~d}^{-1}$ (Table 5). Water column regeneration of $\mathrm{NH}_{4}^{+}$measured in the dark increased through the summer and decreased in the fall (Fig. 3). However, regeneration was greatest in March possibly due to the presence of a brown tide which may have provided additional dissolved organic nitrogen for remineralization. $\mathrm{NH}_{4}{ }^{+}$was primarily taken up in the water column in the light, and net fluxes ranged from -145 to $-45 \mu \mathrm{mol} \mathrm{N} \mathrm{m}{ }^{-2} \mathrm{~d}^{-1}$ or -0.13 to $-0.04 \mu \mathrm{mol} \mathrm{N} \mathrm{l}^{-1} \mathrm{~d}^{-1}$, except in June 1997 , when net regeneration of $\mathrm{NH}_{4}^{+}\left(76 \mu \mathrm{mol} \mathrm{N} \mathrm{m}^{-2} \mathrm{~d}^{-1}\right.$ or

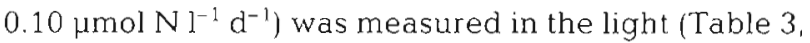
Fig. 3). Bacterioplankton $N$ demand, calculated from bacterioplankton production and $\mathrm{C}: \mathrm{N}=4.3$, ranged from 450 to $2110 \mu \mathrm{mol} \mathrm{N} \mathrm{m}^{-2} \mathrm{~d}^{-1}$ and far exceeded the estimated $\mathrm{NH}_{4}^{+}$regeneration, which may indicate that uptake of dissolved organic nitrogen was important. Phytoplankton $\mathrm{N}$ demand, calculated from gross primary production and $\mathrm{C}: \mathrm{N}$ ratio of 6.6 , ranged from $<10$ to $700 \mu \mathrm{mol} \mathrm{N} \mathrm{m}^{-2} \mathrm{~d}^{-1}$, indicating that the net uptake (in the light) was usually an underestimate of total uptake (Table 4). In the water column, net uptake of $\mathrm{NH}_{4}{ }^{+}$in the light was generally much lower than net regeneration measured in the dark, and there was no seasonal pattern to the variability in fluxes measured in the light (Fig. 3).

The rates of water column $\mathrm{NH}_{4}{ }^{+}$regeneration, calculated as the sum of $\mathrm{NH}_{4}^{+}$release in dark incubations conducted during the day and night, ranged from 124 to $652 \mu \mathrm{mol} \mathrm{N} \mathrm{m}^{-2} \mathrm{~d}^{-1}$ or 0.10 to $0.59 \mu \mathrm{mol} \mathrm{N} \mathrm{l}^{-1} \mathrm{~d}^{-1}$ (Table 4). On 25 June 1997, potential rates of $\mathrm{NH}_{4}{ }^{+}$ uptake and regeneration were estimated using the ${ }^{15} \mathrm{~N}$ isotopic dilution technique in incubations amended with $4 \mu \mathrm{M}{ }^{15} \mathrm{NH}_{4} \mathrm{Cl}$ (Gardener et al. 1991, 1995). Potential regeneration rates were similar in both light $\left(0.10 \mu \mathrm{M} \mathrm{h}^{-1}\right)$ and dark $\left(0.11 \mu \mathrm{M} \mathrm{h}^{-1}\right)$ incubations (Gardner unpubl. data), and were about 3 times the rate estimated from the net change in $\mathrm{NH}_{4}{ }^{+}$measured in the water column during the same period $(0.03 \mu \mathrm{M}$ $\mathrm{h}^{-1}$ ). This suggested that the absence of light and use of net changes in $\mathrm{NH}_{4}{ }^{+}$did not grossly underestimate the regeneration of $\mathrm{NH}_{4}{ }^{+}$in the water column. The presence of light has been reported to increase rates of remineralization in systems with a greater proportion of phytoplankton production (Gardner et al. 1996).

Water column fluxes of $\mathrm{NO}_{3}{ }^{-}+\mathrm{NO}_{2}{ }^{-}$were almost always undetectable, except in June 1997, when samples were analyzed using chemiluminescence detection (Table 5). The more sensitive and precise chemiluminescence method served to verify that the $\mathrm{NO}_{3}{ }^{-}+$

Table 4. Average water column estimates of respiration (R), gross primary production (GPP), bacterioplankton production (BP). bacterioplankton growth efficiency (BGE), phytoplankton nitrogen demand (Phyto. N demand) based on C:N $=6.7$, and bacterioplankton $\mathrm{N}$ demand (Bacterio. $\mathrm{N}$ demand) based on $\mathrm{C}: \mathrm{N}=4.3$, ammonium ( $\mathrm{NH}_{4}{ }^{*}$ ) regeneration, and molar $\mathrm{C}: \mathrm{N}$ radio of dissolved organic matter (DOM) remineralized. All rates are in units of mmol $\mathrm{C} \mathrm{m}^{-2} \mathrm{~d}^{-1}$ or mmol $\mathrm{N} \mathrm{m}^{-2} \mathrm{~d}^{-1}$ Errors are reported as $\pm 1 \mathrm{SD}$

\begin{tabular}{|c|c|c|c|c|c|c|c|c|}
\hline Month & $\mathrm{R}$ & $\mathrm{GPP}$ & $\mathrm{BP}$ & $\begin{array}{c}B G E \\
(\%)\end{array}$ & $\begin{array}{c}\text { Phyto. } \\
\text { N demand }\end{array}$ & $\begin{array}{l}\text { Bacterio. } \\
\text { N demand }\end{array}$ & $\begin{array}{l}\mathrm{NH}_{4}{ }^{+} \\
\text {regeneration }\end{array}$ & $\begin{array}{l}C: N \text { of DOM } \\
\text { remineralized }\end{array}$ \\
\hline June & $27 \pm 2$ & $3 \pm 2$ & $6 \pm 0.7$ & 19 & $<0.01$ & 1.20 & $0.33 \pm 0.06$ & $81 \pm 0.2$ \\
\hline July & $14 \pm 6$ & $0.4 \pm 3$ & $6 \pm 0.4$ & 30 & $<0.01$ & 1.08 & $0.55 \pm 0.17$ & $26 \pm 0.7$ \\
\hline September & $9 \pm 1$ & $3 \pm 1$ & $6 \pm 1.9$ & 38 & 0.10 & 1.35 & $0.65 \pm 0.10$ & $14 \pm 0.2$ \\
\hline November & $7 \pm 2$ & $1 \pm 1$ & $2 \pm 1.0$ & 21 & 0.04 & 0.45 & $0.12 \pm 0.07$ & $55 \pm 0.6$ \\
\hline March & $17 \pm 7$ & $9 \pm 3$ & $9 \pm 1.6$ & 36 & 0.35 & 2.11 & $0.65 \pm 0.46$ & $26 \pm 0.8$ \\
\hline June & $15 \pm 3$ & $6 \pm 2$ & $6 \pm 2.2$ & 28 & 0.70 & 1.37 & $0.28 \pm 0.13$ & $54 \pm 0.5$ \\
\hline
\end{tabular}


Table 5. Water column and benthic net nutrient fluxes ( $\mu \mathrm{mol} \mathrm{N}$ or $\mathrm{P} \mathrm{m}^{-2} \mathrm{~d}^{-1}$ ) measured in light and dark incubations. Daily rates for light and dark incubations were calculated from the number of hours of daylight or night, respectively. All rates are reported as mean $(n \geq 3) \pm 1$ SD. - : not detectable, na: not available due to contamination

\begin{tabular}{|c|c|c|c|c|c|c|}
\hline \multirow[t]{2}{*}{ Date } & \multicolumn{2}{|c|}{$\mathrm{NH}_{4}^{+}$} & \multicolumn{2}{|c|}{$\mathrm{NO}_{3}^{-}+\mathrm{NO}_{2}^{-}$} & \multicolumn{2}{|c|}{ SRP } \\
\hline & Light & Dark & Light & Dark & Light & Dark \\
\hline \multicolumn{7}{|l|}{ Water column } \\
\hline 12-13 Jun 1996 & $-99 \pm 382$ & $182 \pm 35$ & - & - & - & - \\
\hline 23-24 Jun 1996 & - & $314 \pm 102$ & - & - & - & - \\
\hline 10-11 Sep 1996 & $-145 \pm 56$ & $421 \pm 60$ & - & - & - & - \\
\hline $6-7$ Nov 1996 & $-45 \pm 40$ & $45 \pm 32$ & - & - & - & _- \\
\hline 8-9 Mar 1997 & $-114 \pm 111$ & $643 \pm 619$ & - & - & $-116 \pm 0$ & $101 \pm 155$ \\
\hline $24-25$ Jun 1997 & $76 \pm 41$ & $277 \pm 130$ & $9 \pm 10$ & $5 \pm 4$ & - & - \\
\hline \multicolumn{7}{|l|}{ Benthos } \\
\hline 13 Jun 1996 & $253 \pm 136$ & na & - & - & - & _- \\
\hline 25 Jul 1996 & $187 \pm 0.2$ & $-107 \pm 255$ & - & - & - & - \\
\hline $12 \operatorname{Sep} 1996$ & $310 \pm 327$ & $28 \pm 333$ & - & - & - & $76 \pm 77$ \\
\hline 5 Nov 1996 & $112 \pm 233$ & $296 \pm 213$ & - & - & - & \\
\hline 8 Mar 1997 & $363 \pm 293$ & $-228 \pm 101$ & - & - & - & - \\
\hline 24 Jun 1997 & $123 \pm 220$ & $306 \pm 295$ & $-1 \pm 9$ & $6 \pm 23$ & - & - \\
\hline
\end{tabular}

$\mathrm{NO}_{2}{ }^{-}$fluxes were small and variable $\left(9 \pm 5 \mu \mathrm{mol} \mathrm{N} \mathrm{m}^{-2}\right.$ $\mathrm{d}^{-1}$ ). Water column fluxes of SRP were usually below detection, except in March, when fluxes in the water

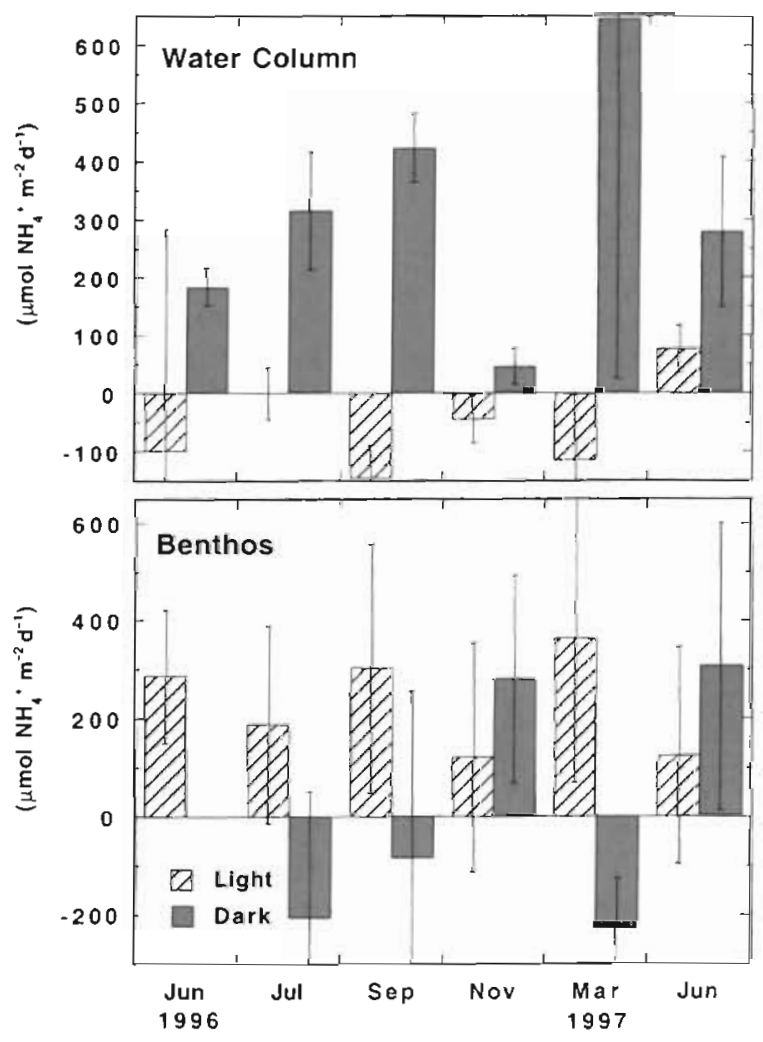

Fig. 3. Average ammonium $\left(\mathrm{NH}_{4}{ }^{+}\right)$fluxes in the water column $(n \geq 3)$ and benthos $(n=4)$ measured in light and dark incubations. Rates are reported as daily rates based on the number of hours of saturating PAR light (for seagrasses) and the number of hours below saturation for light and dark rates, respectively. Error bars represent \pm 1 SD column were -116 and $101 \mu \mathrm{mol} \mathrm{N} \mathrm{m}^{-2} \mathrm{~d}^{-1}$ in the light and dark, respectively (Table 5).

Net benthic $\mathrm{NH}_{4}{ }^{+}$fluxes were always positive in the light and ranged from 112 to $363 \mu \mathrm{mol} \mathrm{N} \mathrm{m}^{-2} \mathrm{~d}^{-1}$ (Table 5, Fig. 3). Net fluxes in the dark were more variable and ranged from -228 to $306 \mu \mathrm{mol} \mathrm{N} \mathrm{m} \mathrm{m}^{-2} \mathrm{~d}^{-1}$. The large standard deviation was in part a result of the major differences in fluxes between vegetated and unvegetated sites. The net flux of $\mathrm{NH}_{4}{ }^{+}$in the light was usually much lower in the unvegetated versus the vegetated site (Fig. 4). The magnitude of the benthic release of $\mathrm{NH}_{4}{ }^{+}$was often lower than $\mathrm{NH}_{4}{ }^{+}$regeneration in the water column (Fig. 5). The $\mathrm{NH}_{4}{ }^{+}$released from the seagrass-dominated sediments on 25 June 1997 (a clear day) was more than double the flux measured on the previous day when light levels were much lower (Table 6). The net fluxes of both $\mathrm{NO}_{3}{ }^{-}+\mathrm{NO}_{2}{ }^{-}$and SRP were almost always undetectable. The samples

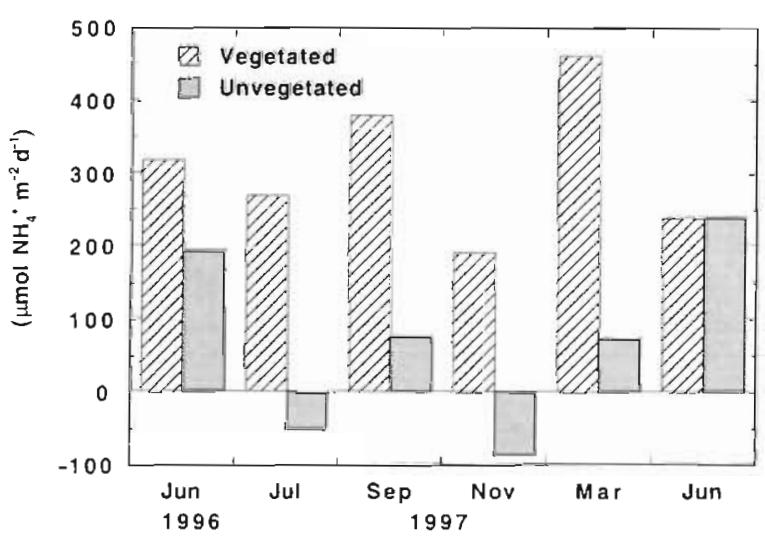

Fig. 4. Benthic ammonium $\left(\mathrm{NH}_{4}{ }^{+}\right)$fluxes measured in the light from vegetated and unvegetated sediments 
Table 6. Total underwater PAR irradiance, benthic not primary production (NPP), dissolved organic carbon (DOC) and ammonium $\left(\mathrm{NH}_{4}{ }^{+}\right)$fluxes measured in the light for seagrass-dominated sediments on 24 June and 25 June 1997. Benthic rates are reported as the mean $(n=4) \pm 1$ SD

\begin{tabular}{|c|c|c|c|c|}
\hline Date & $\begin{array}{c}\mathrm{PAR}^{\mathrm{d}} \\
\left(\mathrm{E} \mathrm{m}^{-2} \mathrm{~d}^{-1}\right.\end{array}$ & $\begin{array}{c}N P P^{b} \\
\left.n m o l ~ C m^{-2} d^{-1}\right)\end{array}$ & $\begin{array}{c}\text { DOC flux } \\
\left(\mathrm{mmol} C \mathrm{~m}^{-2} \mathrm{~d}^{-1}\right)\end{array}$ & $\begin{array}{c}\mathrm{NH}_{4}{ }^{+} \mathrm{flux} \\
\left(\mu \mathrm{mol} C \mathrm{~m}^{-2} \mathrm{~d}^{-1}\right)\end{array}$ \\
\hline 24 Jun 1997 & 14 & $7.7 \pm 1.5$ & $1142 \pm 219$ & $2 \pm 9$ \\
\hline 25 Jun 1997 & 36 & $15.6 \pm 2.4$ & $2260 \pm 1298$ & $21 \pm 26$ \\
\hline
\end{tabular}

when nutrients are in very low concentrations and carbon substrate is readily available (Rhee 1972). In Laguna Madre, water column net uptake of $\mathrm{NH}_{4}{ }^{+}$in the light was always small relative to net regeneration of $\mathrm{NH}_{4}{ }^{+}$in the dark. Phytoplankton demand for $N$ represented only about 0.8 to $34 \%$ of the total $N$ demand in the water column, indicating that heterotrophic uptake was probably responsible for most of the utilization of $\mathrm{NH}_{4}{ }^{+}$ in the water column. Furthermore,

collected in June and analyzed for $\mathrm{NO}_{3}{ }^{-}+\mathrm{NO}_{2}{ }^{-}$using chemiluminescence detection verified that, in fact, the benthic fluxes of $\mathrm{NO}_{3}{ }^{-}+\mathrm{NO}_{2}^{-}$were extremely small and variable (Table 5)

\section{DISCUSSION}

\section{Nutrient limitation of phytoplankton production}

The close proximity of the seagrasses to high concentrations of nutrients and bacterial activity in the benthos can provide them with an advantage over phytoplankton where nutrients are in much lower concentrations (Wetzel 1975, Sandjensen \& Borum 1991). In lower Laguna Madre, low inorganic nutrient concentrations and the release of DOC from the benthos fueling heterotrophic activity (Ziegler \& Benner 1999) limit primary production in the water column. The degree to which phytoplankton are nutrient limited may depend upon the magnitude of allochthonous as well as the macrophytic input of DOC (del Giorgio \& Peters 1994). Bacterioplankton have been found to outcompete phytoplankton for available DIN at times

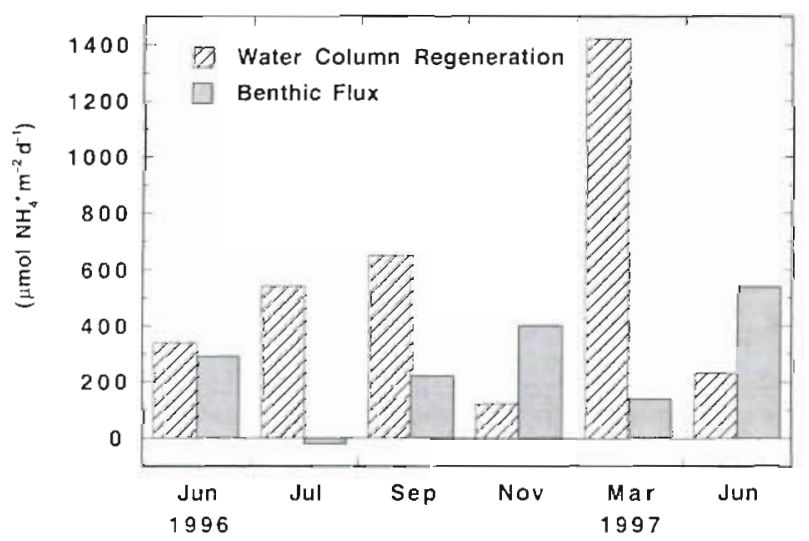

Fig. 5. A comparison of the rates of ammonium $\left(\mathrm{NH}_{4}{ }^{2}\right)$ regeneration in the water column and total daily benthic flux of ammonium potential $\mathrm{NH}_{4}{ }^{+}$uptake rates, measured at the study site on 25 June 1997 using the ${ }^{15} \mathrm{~N}$ isotope dilution approach, were essentially the same in light and dark incubations (W. Gardner unpubl. data).

\section{Benthic source of water column nutrients}

Release of nutrients from the benthos is often important for the growth of phytoplankton in the overlying water (Rowe et al. 1975). In various types of estuaries, benthic nutrient fluxes have been reported to range from -1 to $37 \mathrm{mmol} \mathrm{NH}_{4}{ }^{+} \mathrm{m}^{-2} \mathrm{~d}^{-1},-16$ to $15 \mathrm{mmol} \mathrm{NO}_{3}^{-}+\mathrm{NO}_{2}^{-} \mathrm{m}^{-2} \mathrm{~d}^{-1}$, and -1 to $9 \mathrm{mmol}$ SRP $\mathrm{m}^{-2} \mathrm{~d}^{-1}$ (Cowan et al. 1996 and references cited within). In most shallow estuarine systems studied, the availability of labile organic matter ultimately regulates benthic nutrient regeneration rates (Nixon 1981, Kemp et al. 1992). Net $\mathrm{NH}_{4}{ }^{+}$regeneration rates estimated for temperate seagrass beds ranged from 7 to $106 \mathrm{mmol} \mathrm{N} \mathrm{m}^{-2} \mathrm{~d}^{-1}$ for shallow and deeper sites during different times of the year, suggesting that remineralization in the benthos acts as a major source of nutrients (Dennison et al. 1987). Fluxes of nutrients in shallow tropical environments, such as mangroves, suggest that efficient bacterial activity is responsible for tight recycling of the regenerated nutrients within the sediments (Alongi 1994). The tight recycling of nutrients within the sediments of shallow aquatic ecosystems may prevent benthic remineralization from providing nutrients to the overlying water column.

In subtropical, southern Laguna Madre fluxes of $\mathrm{NH}_{4}{ }^{+}, \mathrm{NO}_{3}{ }^{-}+\mathrm{NO}_{2}{ }^{-}$, and SRP were all much smaller then those reported for many other estuaries, suggesting extremely efficient recycling of nutrients within the sediments in this ecosystem. $\mathrm{NH}_{4}{ }^{+}$was the major form of inorganic $\mathrm{N}$ exchanged between the water column and the benthos. Rates of benthic $\mathrm{NH}_{4}{ }^{+}$ release were in the range of those calculated from measurements of $\mathrm{NH}_{4}$ regeneration and seagrass assimilation for a Zostera marina bed in Alaska 
(88 $\mu \mathrm{mol} \mathrm{N} \mathrm{m}^{-2} \mathrm{~d}^{-1}$; Short 1983). However they were much lower than fluxes reported for Puttalam Lagoon (-14 to $\left.7 \mathrm{mmol} \mathrm{N} \mathrm{m}^{-2} \mathrm{~d}^{-1}\right)$, a more eutrophic tropical seagrass community in Sri Lanka that recejves effluent from local shrimp farming facilities (Johnson \& Johnstone 1995). The low nutrient fluxes and high respiration in the benthos (Ziegler \& Benner 1999) indicated rapid and tight recycling of $\mathrm{N}$ and $\mathrm{P}$ within the sediments in Laguna Madre. $\mathrm{NH}_{4}{ }^{+}$regeneration in the sediments of seagrass beds have been found to approximately equal utilization by seagrasses, suggesting that $\mathrm{N}$ is often tightly recycled within seagrass sediments (Boon et al. 1986) and not a major source of nutrients for the overlying water column. The relatively high nutrient fluxes in Puttalam Lagoon may be indicative of a perturbed seagrass community (Johnson \& Johnstone 1995). The large inputs of nutrients and subsequent reduction in the productivity of the seagrasses in Puttalam Lagoon may have destroyed the tight recycling of nutrients evident and potentially important in southern Laguna Madre where allochthonous input is very small.

Differences in benthic fluxes measured in Laguna Madre on 24 and 25 June 1997 demonstrated that a link may exist between seagrass exudation of DOC and the benthic release of $\mathrm{NH}_{4}{ }^{+}$(Table 6). This difference between 24 and 25 June was not observed in the unvegetated sediments, where fluxes of $\mathrm{NH}_{4}{ }^{+}$ were the same on the 2 consecutive days. Throughout the year, most of the release of $\mathrm{NH}_{4}{ }^{+}$from the benthos occurred in the light and from the seagrassdominated sediments, indicating that the source of $\mathrm{NH}_{4}{ }^{+}$was often related to seagrass exudation and its subsequent remineralization. The greatest light-mediated benthic release of $\mathrm{NH}_{4}{ }^{+}$occurred in March and coincided with the highest rate of benthic net primary production (Ziegler \& Benner 1999) and seagrass tissue $N$ content (Kaldy 1997). In November, when benthic net primary production was lowest (Ziegler \& Benner 1999), the release of $\mathrm{NH}_{4}{ }^{+}$did not appear to be related to any light-mediated process. There is some evidence that amino acids, released by the roots of seagrasses during active photosynthesis, are degraded by bacteria thereby generating $\mathrm{NH}_{4}{ }^{+}$(Jørgensen et al. 1981, Wood \& Hayasaka 1981, Smith et al. 1984). Porewater $\mathrm{NH}_{4}{ }^{+}$concentrations have been observed to increase diurnally in the sediments of some seagrass beds, suggesting that remineralization of $\mathrm{N}$ in root exudates could be a major source of $\mathrm{NH}_{4}{ }^{+}$ (Moriarty et al. 1986, Blackburn et al. 1994, Stapel et al. 1997). Some proportion of this regenerated $\mathrm{NH}_{4}{ }^{+}$ in the benthos may be released into the overlying water column and could account for the small light-mediated release of $\mathrm{NH}_{4}{ }^{+}$measured in Laguna Madre.

\section{Water column remineralization of DOM as a source of nutrients}

Remineralization of DOM was a major source of water column $\mathrm{NH}_{4}{ }^{+}$in lower Laguna Madre. The magnitude of $\mathrm{NH}_{4}{ }^{+}$regeneration in the water column was usually larger than the net release of $\mathrm{NH}_{4}{ }^{+}$from the benthos. $\mathrm{NH}_{4}{ }^{+}$regeneration in the water column was significantly correlated to the release of DOC from the benthos $\left(\mathrm{r}^{2}=0.91, \mathrm{p}<0.05, \mathrm{n}=4\right.$; Ziegler \& Benner 1999), suggesting that benthic release of DOM was fueling the regeneration of $\mathrm{NH}_{4}{ }^{+}$in the water column. The correlation between $\mathrm{NH}_{4}^{+}$regeneration in the water column and water temperature was not significant, indicating that temperature was not as important as the benthic supply of DOM in regulating $\mathrm{NH}_{4}{ }^{+}$ regeneration

Phytoplankton $\mathrm{N}$ demand was always met by the sum of the $\mathrm{NH}_{4}{ }^{+}$regeneration in the water column and the benthic release of $\mathrm{NH}_{4}{ }^{+}$. Bacterioplankton $\mathrm{N}$ demand generally exceeded the supply of $\mathrm{NH}_{4}{ }^{+}$from water column regeneration and the benthic fluxes. The sum of water column $\mathrm{NH}_{4}{ }^{+}$regeneration and benthic release of $\mathrm{NH}_{4}^{+}$represented 37 to $73 \%$ of bacterioplankton $\mathrm{N}$ demand, except in November, when it was about $117 \%$ of bacterioplankton $\mathrm{N}$ demand. This indicated that dissolved organic nitrogen was probably a major source of $\mathrm{N}$ for bacterioplankton during most of the year.

\section{Relationship between the source of DOM and nutrient cycling}

Changes in the availability and composition of benthic-derived DOM in Laguna Madre significantly influenced the cycling of $\mathrm{N}$ in the water column. Bacterioplankton growth efficiencies were significantly correlated to water column $\mathrm{NH}_{4}{ }^{+}$regeneration, with the highest growth efficiencies occurring in March and September (Fig, 6). The $C: N$ ratio of organic matter remineralized in the water column, calculated from water column respiration and $\mathrm{NH}_{4}{ }^{+}$regeneration, varied temporally and ranged from 14 to 81 (Table 4). Because there is no net accumulation of bacterioplankton biomass in Laguna Madre during the day (Chin-Leo \& Benner 1991) these C:N values are representative of the DOM utilized by heterotrophic bacterioplankton. The temporal variability in the $\mathrm{C}: \mathrm{N}$ of the bioreactive DOM and bacterioplankton growth efficiency indicated that the DOM released from the benthos and utilized in the water column was seasonally variable in composition. The $\mathrm{C}: \mathrm{N}$ of the organic matter remineralized in the water column was lowest in September and highest in June, indicating that bio- 


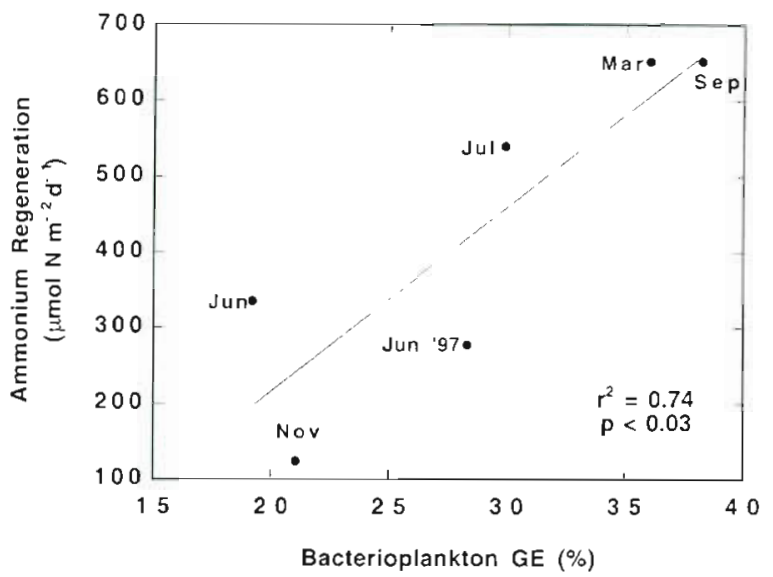

Fig. 6. Linear regression analysis of water column ammonium regeneration versus bacterioplankton growth efficiency (GE)

reactive DOM was enriched in $\mathrm{N}$ during the late summer and relatively depleted in $\mathrm{N}$ during early summer. Processes responsible for the release of DOM, namely exudation and leaching, were probably quite different during these times of the year. During June, benthic net primary production was relatively high and seagrass exudation would be expected to be greatest. Leaching, however, was probably more predominant in September, when seagrasses were beginning to senesce and benthic net primary production was low (Ziegler \& Benner 1999).

Bacterial processes and $\mathrm{N}$ cycling have been found to be closely coupled to photosynthetic production of organic matter in other aquatic environments (Cole et al. 1982, 1988, Coffin et al. 1994). In Laguna Madre, release of DOM from the benthos was found to enhance regeneration of $\mathrm{NH}_{4}{ }^{+}$in the water column. Studies have indicated that efficient regeneration of nutrients by bacterioplankton may only occur when available substrates have a $\mathrm{C}: \mathrm{N}<10$ (Fenchel \& Blackburn 1979, Billen 1984, Goldman et al. 1987). Therefore, bacterial regeneration of $\mathrm{NH}_{4}{ }^{+}$in Laguna Madre may have been due to remineralization of a fraction of DOM with a $\mathrm{C}: \mathrm{N}<10$ or a combination of $\mathrm{C}$-rich and $\mathrm{N}$-rich compounds. Previous studies in seagrass beds have demonstrated that DON constituted the majority of interstitial $N$ (Boon et al. 1986) and the dominant form of $\mathrm{N}$ released from the sediments. Seasonal variations in bacterioplankton growth efficiencies and the C: $\mathrm{N}$ of bioreactive DOM in Laguna Madre suggest that the regeneration of $\mathrm{NH}_{4}{ }^{+}$in the water column is directly linked to the chemical composition of the DOM released from the benthos.

Acknowledgements. The authors especially thank Beau Hardegree for extensive and essential field and laboratory assistance. We would like to thank Wayne Gardner for sharing unpublished data relevant to this work. We also appreciate the assistance of Don Hockaday at the UT-PanAm Coastal Studies Laboratory, South Padre Island, Texas, who provided needed laboratory space and facilities during field trips to lower Laguna Madre. This manuscript was improved by the review and comments of 3 anonymous reviewers. This research was supported by NSF grant DEBB 9420652. This is contribution number 1127 from the University of Texas Marine Science Institute.

\section{LITERATURE CITED}

Alongi DM (1994) The role of bacteria in nutrient recycling in tropical mangrove and other coastal benthic ecosystems. Hydrobiol 285:19-32

Amon RWM, Benner R (1998) Seasonal patterns of bacterial abundance and production in the Mississippi River plume and their importance for the fate of enhanced primary production. Microb Ecol 35:289-300

Biddanda B, Opsahl S, Benner R (1994) Plankton respiration and carbon flux through bacterioplankton on the Louisiana shelf. Limnol Oceanogr 39(6): 1259-1275

Billen G (1984) Heterotrophic utilization and regeneration of nitrogen. In: Hobbie JE. Williams PJl (eds) Heterotrophic activity in the sea. Plenum, New York, p 313-355

Blackburn TH, Nedwell DB, Wiebe WJ (1994) Active mineral cycling in a Jamaican seagrass sediment. Mar Ecol Prog Ser 110:233-239

Boon PI, Moriarty DJW, Saffigna PG (1986) Rates of ammonium turnover and role of amino-acld deamination in seagrass (Zostera Capricorni) beds of Moreton Bay. Aust Mar Biol 91:259-268

Borum J (1985) Development of epiphytic communities on eelgrass (Zostera marina) along a nutrient gradient in a Danish estuary. Mar Biol 87:211-218

Chin-Leo G, Benner R (1991) Dynamics of bacterioplankton abundance and production in seagrass communities of a hypersaline lagoon. Mar Ecol Prog Ser 73:219-230

Chin-Leo G, Benner R (1992) Enhanced bacterioplankton production and respiration at intermediate salinities in the Mississippi River plume. Mar Ecol Prog Ser 87:87-103

Coffin RB, Connolly JP, Harris PS (1994) Availability of dissolved organic carbon to bacterioplankton examined by oxygen utilization. Mar Ecol Prog Ser 101:9-22

Cole JJ, Likens GE, Strayer DL (1982) Photosynthetically produced dissolved organic carbon: an important carbon source for planktonic bacteria. Limnol Oceanogr 27 : $1080-1090$

Cole JJ, Findlay S, Pace ML (1988) Bacterial production in fresh and salt-water ecosystems: a cross-system overview. Mar Ecol. Prog Ser 43:1-10

Cowan JLW, Pennock JR, Boynton WR (1996) Seasonal and interannual patterns of sediment-water nutrient and oxygen fluxes in Mobile Bay. Alabama (USA): regulating factors and ecological significance. Mar Ecol Prog Ser 141: $229-245$

del Giorgio PA, Peters RH (1994) Patterns in planktonic P:R ratios in lakes: Influence of lake trophy and dissolved organic carbon. Limnol Oceanogr 39(4):772-787

del Giorgio PA, Cole JJ, Cimbleris A (1997) Respiration rates in bacteria exceed phytoplankton in unproductive aquatic systems. Nature 385:148-151

Dennison WC, Aller RC, Alberte RS (1987) Sediment ammonium availability and eelgrass (Zostera marina) growth. Mar Biol 94:469-477

Dennison WC, Orth RJ, Moore KA, Stevenson JC, Carter V, 
Kollar S, Bergstrom PW, Batuik RA (1993) Assessing water quality with submersed aquatic vegetation: habitat requirements as barometers of Chesapeake Bay health. Bioscience 43:86-94

Dunton KH (1990) Production ecology of Ruppia maritima L. s.l. and Halodule wrightii Achers. in two subtropical estuaries. J Exp Mar Biol Ecol 143:147-164

Fenchel T, Blackburn TH (1979) Bacteria and mineral cycling. Academic Press, New York

Flores-Verdugo FJ, Day JW, Mee L, Briseno-Duenas R (1988) Phytoplankton production and seasonal biomass variation of seagrass, Ruppia maritima L., in a tropical Mexican lagoon with an ephemeral inlet. Estuaries 11(1):51-56

Fourqurean JW, Jones RD, Zieman JC (1993) Processes influencing water column nutrient characteristics and phosphorus limitation of phytoplankton biomass in Florida Bay, FL, USA: inferences from spatial distributions. Estuar Coast Mar Sci 36:295-314

Gardner WS, Wynne DS, Dunstan WM (1976) Simplified procedure for the manual analysis of nitrate in seawater. Mar Chem 4:393-396

Gardner WS, Herche LR, St. John PA, Seitzinger SP (1991) High-performance liquid chromatographic determination of ${ }^{15} \mathrm{NH}_{4}:\left[{ }^{14} \mathrm{NH}_{4}+{ }^{15} \mathrm{NH}_{4}\right]$ ion ratios in seawater for isotope dilution experiments. Anal Chem 63:1838-1843

Gardner WS, Bootsma HA, Evans C, John PAS (1995) Improved chromatographic analysis of ${ }^{15} \mathrm{~N}:{ }^{14} \mathrm{~N}$ ratios in ammonium or nitrate for isotope addition experiments. Mar Chem 48:271-282

Gardner WS, Benner R, Amon RMW, Cotner JB, Cavaletto JF, Johnson JR (1996) Effects of high-molecular-weight dissolved organic matter on nitrogen dynamics in the Mississippi River plume Mar Ecol Prog Ser 133:287-297

Goldman JC, Caron DA, Dennett MR (1987) Regulation of gross growth efficiency and ammonium regeneration in bacteria by substrate $\mathrm{C}: \mathrm{N}$ ratio. Limnol Oceanogr 32: $1239-1252$

Herzka SZ, Dunton KH (1996) Seasonal photosynthetic patterns of the seagrass Thalassia testudinum in the western Gulf of Mexico. Mar Ecol Prog Ser 152:103-117

Hillman K, Walker DI, Larkum AWD, MCComb AJ (1989) Productivity and nutrient limitation. In: Larkum AWD, McComb AJ, Shepard SA (eds) Biology of seagrasses. Elsevier, Amsterdam, p 635-685

Humm HJ, Hildebrand $\mathrm{HH}$ (1962) Marine algae from the gulf coast of Texas and Mexico. Publ Inst Mar Sci 8:227-268

Iizumi $H_{\text {i }}$ Hattori A, McRoy CP (1982) Ammonium regeneration and assimilation in eelgrass (Zostera marina) beds. Mar Biol 66:59-65

Johnson P, Johnstone R (1995) Productivity and nutrient dynamics of tropical sea-grass communities in Puttalam Lagoon, Sri Lanka. Ambio 24(7-8):411-417

Jørgensen NOG, Blackburn TH, Henriksen K, Bay D (1981) The importance of Posidonia oceanica and Cymodocea nodosa as contributors of free amino acids in water and sediment of seagrass beds. PSZN I; Mar Ecol 2:97-112

Kaldy JE (1997) Production dynamic, reproduction ecology and demography of Thalassia testudinum (turtle grass) from the Lower Laguna Madre, Texas. PhD dissertation, University of Texas at Austin

Kemp WM, Boynton WR, Twilley RR, Stevenson JC, Means JC (1983) The decline of submerged vascular plants in upper Chesapeake Bay: summary of results concerning possible causes. Mar Technol Soc J 17:78-89

Kemp WM, Sampou P, Caffrey J, Mayer M, Henriksen K (1992) Seasonal depletion of oxygen from bottom waters of Chesapeake Bay: roles of benthic and planktonic respira- tion and physical exchange processes. Mar Ecol Prog Ser 85:137-152

Kirchman DL, K'nees E, Hodson RE (1985) Leucine incorporation and its potential as a measure of protein synthesis by bacteria in natural aquatic systems. Appl Environ Microbiol 49:599-607

Lee S, Fuhrman JA (1987) Relationships between biovolume and biomass of naturally derived marine bacterioplankton. Appl Environ Microbiol 53:1298-1303

Middelboe M, Kroer N, Jorgensen NOG, Pakulski D (1998) Influence of sediment on pelagic carbon and nitrogen turnover in a shallow Danish estuary. Aquat Microb Ecol $14: 81-90$

Moriarty DJW, Pollard PC (1982) Diel variation of bacterial productivity in seagrass (Zostera capricorni) beds measured by rate of thymidine incorporation into DNA. Mar Biol 72:165-173

Moriarty DJW, Iverson RL, Pollard PC (1986) Exudation of organic carbon by the seagrass Halodule wrightii Aschers and its effects on bacterial growth in the sediment. Exp Mar Biol Ecol 96:115-126

Moriarty DJW, Roberts DG, Pollard PC (1990) Primary and bacterial productivity of tropical seagrass communities in the Gulf of Carpentaria, Australia. Mar Ecol Prog Ser 61: $145-157$

Nixon SW (1981) Remineralization and nutrient cycling in coastal marine sediments. In: Neilson BJ, Cronin LE (eds) Estuaries and nutrients. Humana, New York, p 111-138

Onuf CP (1996) Biomass patterns in seagrass meadows of the Laguna Madre, Texas. Bull Mar Sci 58:404-420

Orth RJ, Moore KA (1983) Chesapeake Bay: an unprecedented decline in submerged aquatic vegetation. Science 222 $51-53$

Oviatt CA, Rudnick DT, Keller AA, Sampou PA, Almquist GT (1986) A comparison of system $\left(\mathrm{O}_{2}\right.$ and $\left.\mathrm{CO}_{2}\right)$ and $\mathrm{C}-14$ measurements of metabolism in estuarine mesocosms. Mar Ecol Prog Ser 28:57-67

Pedersen MF, Borum J (1993) An annual nitrogen budget for a seagrass Zostera marina population. Mar Ecol Prog Ser 101:169-177

Quammen ML, Onuf CP (1993) Laguna Madre: seagrass changes continue decades after salinity reduction. Estuaries 16(2):302-310

Redfield AC (1958) The biological control of chemical factors in the environment. Am Sci 46:205-221

Rhee GY (1972) Competition between an alga and an aquatic bacterium for phosphate. Limnol Oceanogr 17(4):505-514

Rowe GT, Clifford CH, Smith KL, Hamilton PL (1975) Benthic nutrient regeneration and its coupling to primary productivity in coastal waters. Nature 255:215-217

Sandjensen K, Borum J (1991) Interactions among phytoplankton, periphyton, and macrophytes in temperate freshwaters and estuaries. Aquat Bot 41(1-3):137-175

Short FT (1983) The response of interstitial ammonium in eelgrass (Zostera marina L.) beds to environmental perturbations. J Exp Mar Biol Ecol 68:195-208

Short FT, McRoy CP (1984) Nitrogen uptake by leaves and roots of the seagrass Zostera marina L. Bot Mar 27:547-555

Smith GW, Hayasaka SS, Thayer GW (1984) Ammonification of amino acids by the rhizosphere microflora of Zostera marina L. and Halodule wrightii Aschers. Bot Mar 27 : $23-27$

Solorzano L (1969) The determination of ammonium in natural waters by phenol-hypochlorite method. Limnol Oceanogr 14:799-801

Stapel J, Hemminga MA (1997) Nutrient resorption from seagrass leaves. Mar Biol 128:197-206 
Stapel J, Manuntun R, Hemminga MA (1997) Biomass loss and nutrient redistribution in an Indonesian Thalassia hemprichii seagrass bed following seasonal low tide exposure during daylight. Mar Ecol Prog Ser 148:251-262

Stockwell DA, Buskey EJ. Whitledge TE (1993) Studies on conditions conducive to the development and maintenance of a persistent 'brown tide' in Laguna Madre, Texas. In: Smayda TJ, Shimizu Y (eds) Toxic phytoplankton blooms in the sea. Elsevier, Arnsterdam, p 693-698

Strickland JD, Parsons TR (1972) A practical handbook of seawater analysis, 2nd edn. Bull Fish Res Bd Can 167

Wetzel RG (1975) Limnology, 2nd edn. WB Saunders Company, Philadelphia

Whitledge TE (1993) The nutrient and hydragraphic conditions prevailing in Laguna Madre, Texas before and

Editorial responsibility: Otto Kinne (Editor),

Oldendorf/Luhe, Germany during a brown tide bloom. In: Smayda TJ, Shimizu Y (eds) Toxic phytoplankton blooms in the sea. Elsevier, Amsterdam, p $711-716$

Williams PJL (1981) Incorporation of microheterotrophic processes into the classical paradigm of the planktonic food web. Kiel Meeresforsch 5:1-28

Wood DC, Hayasaka SS (1981) Chemotaxis of rhizoplane bacteria to amino acids comprising eelgrass (Zostera marina L.) root exudate. J Exp Mar Biol Ecol 50:153-161

Ziegler S, Benner R (1998) Ecosystem metabolism of a subtropical seagrass-dominated lagoon. Mar Ecol Prog Ser 173:1-12

Ziegler S, Benner R (1999) Dissolved organic carbon cycling in a subtropical seagrass-dominated lagoon. Mar Ecol Prog Ser 180:149-160

Submitted: September 3, 1998; Accepted: April 30, 1999

Proofs recejved from author(s): October 25, 1999 